\title{
1. The drivers of trademark law reform: perspectives from the academy
}

\author{
Graeme B. Dinwoodie and Mark D. Janis ${ }^{l}$
}

\section{THE DRIVERS OF TRADEMARK LAW REFORM?: PERSPECTIVES FROM THE ACADEMY}

This book is about reforming trademark law and unfair competition, with an emphasis on the U.S., Europe, the U.K., and Australia. We asked some of the world's leading trademark law scholars to identify a problem area in contemporary trademark law, articulate aspirations for tackling that problem, and supply a normative framework to guide future reform proposals that would address the problem. The chapters of this book are the response. Our contributors - notorious overachievers all- have predictably gone further, offering concrete reform prescriptions and, in many instances, practical suggestions for implementing those prescriptions.

Is this at all remarkable? In some respects, no: scholars are expected to disrupt the conventional discourse and to chart a path that takes it in a new direction. And many trademark law scholars have done so over the years. ${ }^{2}$ As any of us could attest, while it is exhilarating to take up the mantle of sage and visionary, it is also frequently maddening when innovative and worthy proposals fail to inspire real change.

This moment in trademark law discourse may be different. The trademark law professorate has grown considerably larger in recent years, especially in the U.S. More outlets exist for circulating scholarly proposals, rapidly and widely. And the rise of online commerce and media has highlighted the importance of branding to an extent not before seen in our lifetimes, creating an engaged audience of policymakers.

1 Professors Dinwoodie and Janis thank the following for excellent research assistance: Nick Eitsert; Peyton Gilliatt; Sarah Kelly; Taylor Lavender; Melanie Magdun; Catherine Morgan; Matthew Spegele; Allison Strong.

2 See, e.g., Frank I. Schechter, The Historical Foundations of the Law Relating To Trade-MARKs (1925); Frank I. Schechter, The Rational Basis of Trademark Protection, 40 HaRv. L. Rev. 813 (1927) (credited as the inspiration for anti-dilution provisions); Ringling Bros.-Barnum \& Bailey Combined Shows, Inc. v. Utah Div. of Travel Dev., 170 F.3d 449 (4th Cir. 1999) (offering an account of Schechter's influence). Schechter's work continues to pique scholarly interest. See, e.g., Barton Beebe, The Suppressed Misappropriation Origins of Trademark Antidilution Law: The Landgericht Elberfeld's Odol Decision and Frank Schechter's The Rational Basis of Trademark Protection, in Rochelle Dreyfuss \& JANE Ginsburg (eds.), Intellectual Property at the Edge: The Contested Contours of IP (2014); Robert Bone, Schechter's Ideas in Historical Context and Dilution's Rocky Road, 24 Santa Clara Comp. \& High Tech. L.J. 469 (2008). 
Writing nearly a quarter-century ago, Professor Robert Denicola offered an account of the legislative reform process in U.S. trademark law that aligns with familiar public choice narratives. Reflecting on the 1988 Trademark Revision Act, ${ }^{3}$ which introduced the intent-to-use provisions into U.S. trademark law, ${ }^{4}$ Denicola characterized the legislative process as "problematic." Association (INTA) was "single-handedly responsible" for the Act, Denicola asserted. ${ }^{6}$ INTA had adeptly organized owners of well-known trademarks to exert influence, while small businesses, speech advocates, and others were "left in the unenviable position of relying on public-spirited academic economists, or even law professors." " Dolores K. Hanna, President of the United States Trademark Association (USTA, INTA's predecessor) in the mid-1980s, provided a more celebratory spin in a 2003 retrospective that recounts how the organization established a powerful committee (the "Trademark Review Commission") to formulate legislative proposals and present them to members of Congress. ${ }^{8}$ But while Hanna stated that "[i]t was important to assemble a diverse group of trademark practitioners as members of [the Commission] to ensure that no points of view would be overlooked," her list of Commission members reinforced Denicola's point: other than Professor McCarthy, the Commission was composed predominantly of lawyers from elite law firms and the legal departments of large multinational corporations. ${ }^{10}$

Viewed from today's vantage point, Hanna's Commission roster tells yet another tale. The top five brands in the world in 2020, according to Forbes, were held by Apple, Google, Microsoft, Amazon, and Facebook, respectively. ${ }^{11}$ None of those companies were represented on the Trademark Review Commission - indeed, several did not even exist at the time. To be sure, INTA today is an even larger, more diverse, and (as reflected in its name change from the USTA to INTA in 1993) explicitly international organization, and while a modern equivalent of a Trademark Review

\footnotetext{
3 Pub. L. No. 100-667, effective November 16, 1989, codified at 15 U.S.C. $\S \S 1051-1128$ (1988).

4 See Graeme B. Dinwoodie \& Mark D. Janis, Trademarks and Unfair Competition: LAW AND Policy 282-84 (5th ed. 2018).

5 Robert C. Denicola, Some Thoughts on the Dynamics of Federal Trademark Legislation and the Trademark Dilution Act of 1995, 59 Law \& Contemp. Probs. 75, 80 (1996). See also Stephen L. Carter, The Trouble with Trademark, 99 YALE L.J. 778-85, 795-800 (1990) (critiquing the intent-to-use provisions on economic and trademark policy grounds and offering reform suggestions).

$6 \quad I d$.

7 Id.

8 Dolores K. Hanna, Personal Recollections: The Trademark Review Commission, 93 TM. REP. 46, 47 (2003).

$9 \quad$ Id.

$10 \quad I d$.

11 https://www.forbes.com/the-worlds-most-valuable-brands/\#3614dac5119c (August 25, 2020).
} 
Commission would contain many new faces, perhaps the new large brand owners would settle into the same roles and project the same interests as their predecessors. ${ }^{12}$

But, then again, maybe not. Some modern trademark law scholars, including some of the contributors to this volume, remain hopeful that a proactive legislature could be the agent of significant trademark law reform. For example, Professor Bill McGeveran has argued that Congress should pass legislation fortifying permissible use defenses in U.S. trademark law. ${ }^{13}$ Similarly, Professor Michael Grynberg has proposed that Congress consider enacting detailed safe harbors for permissible uses of trademarks. ${ }^{14}$ In Europe, a report commissioned from the Max Planck Institute framed reform discussions about refinements to European trademark law. ${ }^{15}$ Indeed, in recent years, scholarly influence has transcended national boundaries, because the transnational nature of the scholarly trademark community is such that one can frequently detect the influence of overseas scholarship in the work of trademark scholars. The Trademark Scholars Roundtable that we have hosted for more than a decade reflects this dynamic.

Most recently, the newly-minted Trademark Modernization Act in the U.S. owes a considerable debt to scholarly work reimagining the registration process ${ }^{16}$ and challenging the conventional wisdom that the supply of marks is infinite. ${ }^{17}$ The Trademark Modernization Act illustrates that scholarly inputs to the legislative

12 This is not to suggest that bar organizations invariably act in lockstep in trademark reform debates. Indeed, the debate in the U.S. in 2020 leading to the enactment of the Trademark Modernization Act provide some evidence to the contrary. See, e.g., Intellectual Property Owners Association Resolution on Trademark Modernization Act, <https://ipo.org/ index.php/trademark-modernization-act/> (opposing proposals for ex parte reexamination but supporting proposals for expungement proceedings); Anne Gilson LaLonde, U.S. Trademark Modernization Act Signed Into Law (Jan. 6, 2021), https://www.inta.org/u-s-trademark -modernization-act-signed-into-law/ (reporting on a 2020 INTA resolution opposing proposals for ex parte reexamination and expungement proceedings).

13 William McGeveran, The Trademark Fair Use Reform Act, 90 B.U.L. Rev. 2267 (2010)

14 Michael Grynberg, The Judicial Role in Trademark Law, 52 B.C. L. Rev. 1283, 1340 (2011) (expressing skepticism about the prospects for trademark reform via the judiciary, and implicating the courts in the post-1988 expansion of trademark rights). Cf. Graeme B. Dinwoodie, The Common Law and Trade Marks in an Age of Statutes, in L. BentLy, C.W. NG \& G. D’Agostino (Eds), The Common Law of Intellectual Property: Essays in Honour of Professor David VAver 331, 352 (2010).

15 For the Institute's most recent major report, see Max Planck Institute for Intellectual Property and Competition Law, Study on the Overall Functioning OF THE European Trade Mark System (2011), https://op.europa.eu/en/publication-detail/-/ publication/5f878564-9b8d-4624-ba68-72531215967e.

16 For example, work by Rebecca Tushnet, which Prof. Tushnet discusses and expands on infra ch. 3.

17 For example, work by Barton Beebe and Jeanne Fromer, which animates their contribution to this volume, infra ch. 1. 
process of trademark reform can conceivably bear fruit. ${ }^{18}$ Time will tell whether the Act's provisions will achieve the objectives that reform proponents seek.

For many other scholars, the likeliest path of trademark reform is to work through the judiciary. ${ }^{19}$ In part, this is the product of pragmatism: scholarly writings are more likely to find purchase among judges than legislators, and strategic amicus briefs building upon or incorporating scholarly writings can have a real and immediate impact. ${ }^{20}$ In part, this may also reflect an inherent quality of trademark law, at least as it has developed in the U.S.: the Lanham Act codifies many common law concepts, sometimes incompletely, sometimes in open-textured terms, often leaving abundant room for judicial imagination (setting aside the questions of whether and how that imagination might be deployed, which may implicate jurisprudential proclivities that extend far beyond the realm of trademark policy). ${ }^{21}$

In part, the discourse between trademark scholars and the judiciary enjoys a long tradition, although the ranks of trademark scholars in the twentieth century were relatively thin compared to today. In addition to invoking the classic treatise writers who frequently inserted their own views into their well-cited books, ${ }^{22}$ U.S.-based trademark scholars may call to mind academic leadership in the drafting of the Restatement (3d) of Unfair Competition in the mid-1990s. Reflecting on that task, Professors Denicola and Perlman pointed out that the task of drafting the Restatement (Third) of Unfair Competition was less a matter of reiterating "crisp rules and bright line tests" than articulating "broad standards and catalogues of relevant factors." 23 While the contextual nature of unfair competition law may have necessitated this approach (as Denicola and Perlman said), ${ }^{24}$ that should not detract from the fact that the act of formulating those standards inevitably required normative choices in addition to mastery of the doctrine. ${ }^{25}$ These places in trademark law, where the normative

18 While we have focused our remarks on legislative proposals, regulatory reform may turn out to be the most fertile area for scholarly efforts in the near term, especially given the increased scholarly attention to the details of the registration process.

19 See infra Part I of this volume.

20 See, e.g., United States Patent and Trademark Office v. Booking.com B.V., 140 S.Ct. 2298, 2307 n. 6 (2020) (citing a trademark scholars' amicus brief urging caution in the use of survey evidence); Iancu v. Brunetti, 139 S.Ct. 2294, 2300 (2019) (citing a trademark scholars' amicus brief on variations in the PTO's application of the scandalousness bar to registration).

21 See Graeme B. Dinwoodie, Developing Defenses in Trademark Law, 13 LewIS \& Clark L. Rev. 99 (2009).

22 J. Thomas McCarthy, Trademarks and Unfair Competition (5th Ed. 2017); louis Altman \& Malla Pollack, Callman on Unfair Competition, Trademarks, and Monopolies (2016).

${ }^{23}$ Robert C. Denicola \& Harvey S. Perlman, A Foreword to the Symposium on the Restatement of Unfair Competition, 47 S. C. L. Rev. i, ii (1996).

${ }^{24} I d$. at ii (stating that in unfair competition law, "context is so often everything").

$25 I d$. (acknowledging that the drafting project called on them to proceed beyond precedent in certain areas and noting that they "sought to rely on analysis and advocacy rather than fiat" when extending the Restatement beyond precedent). 
underpinnings of doctrine are weak, or simply have remained long unarticulated, are the places where reform-minded trademark scholars can add immense value.

\section{FIRST STEPS TOWARDS A TRADEMARK LAW REFORM AGENDA?}

This volume, we hope, serves as a useful forum for communicating serious and thoughtful trademark law reform proposals. We should say here that we have made minimal effort to strategically coordinate these proposals to formulate a coherent agenda. Quite the opposite-we have turned brilliant scholars loose with few constraints other than to reflect on trademark law problems and how they might be solved. The resulting chapters represent the best of cutting-edge trademark law thinking. If they do not fall into place tidily as a comprehensive blueprint for trademark law reform (and, let us be clear at the outset, they do not), they do provide raw material from which such a blueprint could be drawn up.

For the reader's convenience, we have organized the chapters in this volume into three broad groups, the first dealing with reforms directed primarily at the work of registration authorities; the second addressing reforms to the rules of trademark protectability and the boundaries between trademark and other intellectual property regimes; and the third dealing with reforms to the rules that govern trademark enforcement and the scope of protection. The groupings are rough, and readers will find that some chapters do not confine themselves exclusively to the topic indicated. As readers will appreciate, this simply reflects the richness of the chapters, and the interlocking nature of many trademark doctrines.

The chapters in Part I all address the work of the registration authorities. The contributions here represent an especially important and welcome trend in trademark scholarship toward examining and rethinking the administrative machinery in trademark registration systems. The enterprise is not limited to matters of administrative process. It also includes close analysis of how substantive trademark rules operate and, in some sense, are reshaped by, that process. Trademark scholars (particularly those writing about U.S. law) have left this area relatively unattended for too long. ${ }^{26}$ It is a challenging area to study, requiring both a mastery of the administrative arcana of trademark practice and a keen sense of how administrative practices (written and sometimes unwritten) actually play out, matters that may be second nature to sophisticated practitioners but are not always transparent to scholars.

26 This is perhaps not surprising given the traditional view that trademark registration in the U.S. system serves merely as a vehicle for recognizing pre-existing rights that were established through operation of common law, along with providing some enforcement advantages. Whether this traditional view of registration still holds today is a matter of some debate. See, e.g., Matal v. Tam, 137 S.Ct. 1744, 1752 n.1 (2071) (declining to resolve whether a mark that is barred from registration under Lanham Act $\S 2$ could nonetheless be enforced through a Lanham Act $\S 43($ a) action). 


\section{Part I}

Barton Beebe and Jeanne Fromer open Part I with an extension of their previous work $^{27}$ on the problems of trademark depletion (fewer potential marks remaining to be claimed by any potential mark owner) and trademark congestion (larger numbers of different mark owners seeking rights to an already-claimed mark) in the U.S. trademark system. ${ }^{28}$ Their primary recommendations are to ratchet up maintenance and renewal fees (possibly calibrating these fees to reflect the intensity of depletion or congestion problems) and to intensify the U.S. Patent and Trademark Office's (USPTO's) effort to audit registrations for dubious claims of use. ${ }^{29}$ These suggested reforms are intriguing in that they presumably could be implemented rapidly, and the heavy lifting would be done by the agency. Of course, suggestions to raise fees are invariably perilous politically, and might be feasible only if accompanied by steep discounts for small entities, which might in turn hamper their mark-conserving and decongesting potential. Beebe and Fromer also suggest that other, more ambitious reforms be considered, such as a heightened secondary meaning requirement. And they recognize that to the extent that claims of unregistered rights also contribute to depletion and congestion, reforms would be needed there, too.

Continuing the focus on reforms that could be effectuated by way of the rules governing the registration process, Robert Burrell and Michael Handler urge that registration authorities more closely scrutinize the ways in which mark owners frame their registration documents, particularly those aspects of registration documents that establish the scope of rights. ${ }^{30}$ Drawing on examples from Australian and European practice, Burrell and Handler assert that the process of registration too often facilitates unduly broad claiming of rights. For example, they argue that mark owners frequently are able to register "hybrid" marks composed of a distinctive word coupled with numerous other visual indicia (e.g., a container shape in a particular color), with a protectability analysis that never considers the extent to which the visual indicia

27 Barton Beebe \& Jeanne C. Fromer, Are We Running Out of Trademarks? An Empirical Study of Trademark Depletion and Congestion, 131 Harv. L. Rev. 945 (2018). See also Barton Beebe \& Jeanne C. Fromer, Trademark Depletion in a Global, Multilingual Economy: Evidence and Lessons from the European Union (forthcoming 2021). These articles reflect not only the growth of empirical scholarship in trademarks, but also recognition of the value of comparative analysis.

28 See infra, Chapter 2.

29 These observations caught the attention of Congress in a hearing that lead to the enactment of the Trademark Modernization Act of 2020. See Statement of Professors Barton Beebe and Jeanne Fromer, U.S. Senate, Comm. Of the Judiciary, Subcomm. on Intellectual Property (Dec. 3, 2019), <https://www.judiciary.senate.gov/imo/media/doc/Beebe Testimony.pdf $>$.

30 See infra, Chapter 3. American scholars have also noted their concerns about the relationship between the scope of rights as defined for registration (or claimed in litigation) and the scope as defined for enforcement. See, e,g., Mark A. Lemley and Mark P. McKenna, Scope, 57 WM. \& MARY L. Rev. 2197 (2016). 
would themselves be registrable. ${ }^{31}$ When a third party appropriates the visual indicia but not the word mark, a difficult question arises as to the scope of the mark owner's rights.

A response, Burrell and Handler suggest, would be to have registration authorities require applicants to disclaim portions of hybrid marks that fall outside the scope of what the applicant means to claim. ${ }^{32}$ In turn this could provide the basis for limiting the scope of rights at the enforcement stage - by way of a doctrine of prosecution history estoppel or the like. Burrell and Handler also identify other forms of overclaiming (for example, applicants who specify a much more extensive list of goods and services than the applicant ever plausibly expects to produce), ${ }^{33}$ and suggest corresponding reforms that can be implemented as part of the registration process (again with a focus on registration schemes as they operate in Australia and Europe). ${ }^{34}$

Rebecca Tushnet's chapter ${ }^{35}$ echoes the theme that the registration system in the U.S. is clogged with too many applications, and adds the concern that applicants have too much latitude to represent that rights are relatively narrow during the registration process (and thus are more readily registrable), and then subsequently represent that those rights are relatively broad for enforcement purposes. In addition to tightening use and distinctiveness requirements, she recommends (like Burrell and Handler) the use of a robust prosecution history estoppel doctrine. Recognizing that these suggestions might simply induce mark owners to opt out of registration - a fear that is particularly acute in the United States, where the domains of trademark and unfair competition barely diverge - Professor Tushnet also suggests restrictions on remedies available for infringement of unregistered marks, among other suggestions.

Professor Tushnet's suggestions attest to the potential difficulties of piecemeal reform. Trademark doctrines are interconnected in sometimes complex ways, and the challenge of reforming the registration system without significantly undermining registration incentives is not trivial. Politics presents another (perhaps) impossibly high hurdle. To this point, Professor Tushnet offers an intriguing rejoinder: incumbents who may be perceived as benefiting most from the registration system status

31 Analogously, U.S. cases on inherent distinctiveness of logo marks recognize that some or all elements of an alleged logo mark might not be "capable of creating a commercial impression distinct from the accompanying words." Seabrook Foods, Inc. v. Bar-Well Foods, Ltd., 568 F.2d 1342, 1344 (CCPA 1977).

32 For guidance on the use of disclaimers in U.S. practice, see Disclaimer of Elements in Marks, Trademark Manual of Examining Procedure 1213 (Oct. 2018).

33 See Sky v. SkyKick (C-371/18) ECLI:EU:C:2020:45 (CJEU 2020); Chartered Institute of Patent Attorneys v. Registrar of Trade Marks ("IP TRANSLATOR") (C-307/10) ECLI:EU: C:2012:361 (CJEU 2012).

34 In the U.S., concerns about the lack of correspondence between assertions of use and proof of use induced the USPTO to establish the Post Registration Proof of Use Audit Program. See 37 C.F.R. $\S \S 2.161(\mathrm{~h}), 7.37(\mathrm{~h})<$ https://www.uspto.gov/trademarks/maintain/ post-registration-audit-program $>$ (describing the program).

${ }_{35}$ See infra, Chapter 4. The chapter extends the author's prior work. Rebecca Tushnet, Registering Disagreement: Registration in Modern American Trademark Law, 130 HaRv. L. REv. 867 (2017). 
quo - large brand owners - might not inflexibly resist any and all calls for reform that involve curtailing rights. This is because brand owners might view some such curtailments as serving their own long-term interests. For example, Professor Tushnet points out that large brand owners supported tightening of the fame requirement for dilution to require national fame and eliminate niche market fame, and also expressed some support for the PTO's audit for compliance with use requirements. This is an important reminder of the need to set aside simplistic labels lest the enterprise of trademark law reform devolve into an endless scuffle between "expansionists" and "restrictionists."

\section{Part II}

In Part II we take up reform proposals directed to the substantive law establishing subject matter boundaries and other aspects of trademark validity. Martin Senftleben addresses the subtleties of the trademark/copyright interface, ${ }^{36}$ adopting as his basis for discussion the importance of preserving the cultural meaning of artworks. The practice of permitting cumulative copyright and trademark protection for cultural symbols, argues Professor Senftleben, constrains artists' freedom to create derivative works using those cultural symbols. Cultural follow-on innovation may be burdened, and the symbol's cultural meaning may be distorted by its affiliation with commercial marketing. Moreover, the checks and balances existing within the modern trademark regime (particularly within doctrines such as distinctiveness and functionality) are not sufficiently adept to head off these problems. Accordingly, focusing on European law, Professor Senftleben proposes that the trademark system incorporate a subject matter exclusion under which artistic works could be excluded from trademark protection on grounds of public order and morality. ${ }^{37}$ Professor Senftleben would craft this exclusion to apply both to the cumulation of extant copyright and trademark in cultural icons that are the basis for character merchandising (such as cartoon characters), as well as trademark protection that appropriates cultural public domain material (such as classic paintings).

Caitlin Canahai and Mark McKenna ${ }^{38}$ take aim at product configuration trade dress as a form of protectable trademark subject matter. Under their proposal, product

36 See infra, Chapter 5. These subtleties have proven to be challenging in the U.S., too. See, e.g., Dastar Corp. v. Twentieth Century Fox Film Corp., 539 U.S. 23 (2003). For reflections on the Court's efforts in Dastar, see Graeme B. Dinwoodie, Trademark and Copyright: Complements or Competitors?, in Jane C. Ginsburg \& June M. BeseK (Eds), Adjuncts And Alternatives to Copyright - Proceedings of the AlAi Congress June 498 (2002).

37 Whether these considerations underlie the U.S. Supreme Court's policing of the trademark/copyright boundary in Dastar is a matter of conjecture. Graeme B. Dinwoodie, Concurrence and Convergence of Rights: The Concerns of the U.S. Supreme Court, in F.W. Grosheide and Jan J. Brinkhof (Eds), Crossing Borders: Between Traditional and ACTUAL 5 (2005). Moreover, in U.S. law, excluding trademark registration on grounds of morality triggers First Amendment concerns. Iancu v. Brunetti, 139 S.Ct. 2294 (2019).

38 See infra, Chapter 6. 
configuration trade dress would not be registrable. This could be accomplished by legislative change, although some courts may be moving in this direction already by interpreting the functionality doctrine as precluding trade dress protection for any subject matter that is de facto functional. ${ }^{39}$ Product configuration claims could still be asserted via the prohibition of unfair competition in Lanham Act Section 43(a), but no comprehensive anti-copying injunctive relief would be available. Instead, injunctive relief would be limited to labeling and/or packaging requirements designed strictly to address potential harms from acts of passing off. ${ }^{40}$ This is an interesting proposal given the history of complaints about Section 43(a) trade dress assertions lacking ex ante notice and thus serving as an ambush tactic by firms defining their trade dress post hoc for litigation purposes. In addition, it would be interesting to know how often assertions of product configuration trade dress today result in liability and broadly prohibitive injunctions, and therefore whether the proposed change would materially change the dynamics of settlement.

Annette Kur's chapter poses an intriguing question: should the doctrine of aesthetic functionality (the protection bar against value-conferring signs, to put it in European terms) be eliminated from EU trademark law? ${ }^{41}$ She answers that it should. The provision excluding such signs from registration is both unclear in its objectives and in its scope, Professor Kur argues. However, the recommendation comes with significant caveats: the aesthetic functionality doctrine should be eliminated only if other safeguards are firmly in place. First, if the value of a mark demonstrably lies not in its established recognition as a signifier of origin, but rather in the aesthetic or otherwise value-conferring aspects of the sign itself, the mark should not be registrable. ${ }^{42}$ Second, a competition-sensitive approach (one that accounts for the "need to keep free") should infuse trademark doctrines both at the validity and enforcement stages. So, for example, a mark may be proven to have acquired distinctiveness, but may still be unregistrable if a comprehensive evaluation of interests involved suggests that the interest in preserving competition outweighs the interest in shielding consumers from confusion. Professor Kur acknowledges that this "package" approach presents

39 See, e.g., Ezaki Glico Kabushiki Kaisha v. Lotte Int'l America Corp., -- F.3d ---, 2021 WL 253451 (3d Cir. Jan. 26, 2021). As Canahai and McKenna acknowledge, abolishing registration for product configuration trade dress could have implications for U.S. compliance with the TRIPS Agreement. See Graeme B. Dinwoodie \& Annette Kur, Non-Conventional Marks and the Obstacle of Functionality: WIPO's Role in Fleshing Out the Telle Quelle Rule, in Sam Ricketson (Ed.), Research Handbook on the World Intellectual Property Organization 131, 139 (2020).

40 Under current law, owners of rights in distinctive, but functional designs may be entitled to such relief. See, e.g., Graeme B. Dinwoodie, The Death of Ontology: A Teleological Approach to Trademark Law, 84 Iowa L. Rev. 611, 746-51 (1999).

41 See infra, Chapter 7.

42 U.S. law incorporates this concept by inquiring whether the exclusive use of trade dress "would put competitors at a significant non-reputation-related disadvantage," a test (at least) for aesthetic functionality. TrafFix Devices, Inc. v. Mktg. Displays, Inc., 532 U.S. 23, 32 (2001). 
its own subtleties, but argues that it is still preferable to a doctrinal approach that is facially simple but formalistic in application and not sufficiently responsive to competition policy concerns. Professor Kur's suggestion aligns with those of some other contributors to this volume in highlighting the interconnectedness of trademark doctrine and normative concerns, and the challenges that this interconnectedness poses for reform efforts.

Dev Gangjee's contribution to the book likewise addresses the themes of trademark subject matter and boundary-policing, but via a theoretical lens. ${ }^{43}$ Professor Gangjee grapples with his skepticism, shared by many scholars, that incentivizing innovation could form a normative basis for justifying trademark protection. ${ }^{44}$ This is a topic worth exploring, Professor Gangjee notes, because the rhetoric of innovation appears more and more frequently in various policy documents from the World Intellectual Property Organization (WIPO), the International Trademark Association ("INTA"), and elsewhere. For example, some such documents speak in terms of a feedback cycle between brands and innovation, whereby brands drive innovation and innovation in turn drives branding. Professor Gangjee concludes that the scholarly consensus has it mostly right: there is no necessary connection between trademark protection and innovation. While some marks surely reflect an underlying investment in innovation, Professor Gangjee reminds us that trademark registries do not, of course, test whether goods or services associated with a mark are in some sense innovative. Moreover, as the chapter points out, even if one were to take this underlying investment seriously as a normative matter, one ought also to take full account of the prospect that trademark protection could in some instances retard the diffusion of innovation, and ask whether boundary-policing doctrines such as functionality, or doctrines that preserve the freedom to compare product attributes via comparative advertising, are likewise animated by innovation concerns.

Jake Linford's chapter ${ }^{45}$ targets the use of consumer surveys in USPTO and court proceedings, taking on the well-known problem that such surveys are too costly and complex, disadvantaging some classes of would-be mark owners and imposing significant costs on those accused of violating trademark rights. ${ }^{46}$ Linford addresses

43 See infra, Chapter 8.

44 Deciding what constitutes "innovation" is likely to be critical. If innovation is limited to the production of novel (in the patent sense) advancements or original (in the copyright sense) creations, skepticism about trademark law's ability to induce such innovation may be well-founded. But if advances in marketing and product differentiation count as socially-desirable innovation, then trademark law may have a more natural connection to innovation. See Jonathan Aldred, The Economic Rationale of Trade Marks: An Economist's Critique, in Lionel Bently, Jennifer Davis \& Jane Ginsburg, (Eds) Trademarks and BRANDS: AN INTERDISCIPLINARY CRITIQUE 267-281 (2008) (discussing different conceptions of innovation).

45 See infra, Chapter 9.

46 The value of survey evidence was a point of contention among U.S. Supreme Court justices in an important genericness decision. Booking.com, 140 S.Ct. at 2314 (Breyer, J., dissenting) (asserting that consumer surveys "may be an unreliable indicator of genericness" such 
two categories of costs: the costs of formulating and executing surveys (including the cost of finding survey participants), and the cost of hiring survey experts to oversee and interpret the results of surveys. As to the first category, Linford makes the case for the use of Amazon's Mechanical Turk (MTurk) to generate consumer surveys at a significant cost saving, and argues that such surveys, properly conducted, should be deemed to satisfy applicable evidentiary standards both in USPTO proceedings and in the courts. As to the second, Linford is perhaps less sanguine about the prospects for quick and effective reform, a major concern since (as Linford acknowledges) paying the experts is easily the largest expense connected with consumer surveys in trademark proceedings. Linford does point out that U.S. admissibility standards for scientific evidence certainly do not compel parties to produce the highest paid experts, but in the heat of disputed proceedings, the parties may be driven more by considerations of the persuasive force of the evidence than by whether it clears the bar for admissibility.

Laura Heymann's chapter ${ }^{47}$ rounds out Part II. The central argument here is that trademarks should be understood to function as proper names. Like proper names, they "simply denote - they have no meaning or truth value," Professor Heymann asserts, and they can be used in many ways without losing their ability to serve as referents. Recognizing this "naming function" of trademarks would have implications for several trademark validity doctrines, according to Professor Heymann. She discusses three: the prohibition against deceptive marks; trademark abandonment; and the Section 2(a) registration bar against marks that are "immoral," "scandalous," or "disparaging," ruled unconstitutional in Tam $^{48}$ and Brunetti. ${ }^{49}$ She argues that these doctrines are demonstrably wrongheaded, at least in some applications, when trademark's naming function is considered. For example, the naming function could counsel in favor of modifying trademark abandonment rules to give greater credence to residual goodwill where a mark (as a name) continues to serve as a referent in the minds of consumers long after the mark owner has ceased producing products bearing the mark.

\section{Part III}

In Part III, we turn to reform proposals that bear most directly on trademark scope and enforcement rules. This Part begins with a contribution from Bob Bone, ${ }^{50}$ who

that a rule that makes genericness turn primarily on survey evidence is unwise). See also id. at 2309 (Sotomayor, J., concurring) (agreeing with the dissent that "[f]laws in a specific survey design, or weaknesses inherent in consumer surveys generally, may limit the probative value of surveys in determining whether a particular mark is descriptive or generic" and declaring that surveys are not "the be-all and end-all" in genericness determinations).

47 See infra, Chapter 10.

48 Matal v. Tam, 137 S.Ct. 1744 (2017).

49 Iancu v. Brunetti, 139 S.Ct. 2294 (2019).

50 See infra, Chapter 11. 
addresses the likelihood-of-confusion test. Professor Bone advocates overhauling the multifactor test by introducing an assessment of trademark-related harm into the analysis. Any proposed expansion of the scope of trademark rights should be justifiable only when the case can be made that the expansion would redress a defined harm. Mark owners should also be compelled to prove harm in non-competing goods cases, Professor Bone argues.

In addition, to facilitate summary disposition and reduce chilling effects in expressive use cases, Professor Bone would require that trademark owners plead and prove actual confusion and a "significant risk of trademark-related harm." This particular motivation for reform may echo Justice Scalia's argument that the need to curtail strike suits is itself a justification for dialing back trademark protection independent of other considerations of trademark policy. ${ }^{51}$ Professor Bone also urges that reform proposals proceed "globally" - that is, that they act on the premise that trademark doctrines are an integrated whole. For example, a proper reform might address both a change to infringement doctrine and a change to fair use defenses. Of course, a global approach to reform is likely to create significant institutional demands. It may be difficult for a court in a given case to pull off a truly global reform, for example.

Jennifer Davis's chapter, like Michael Grynberg's chapter following it, addresses the judicial construct of the "average consumer." 52 Professor Davis focuses on the deployment of that construct in a setting in which its contours are not clear: passing off actions in the U.K. She shows that the assumed characteristics of the average consumer in "classic" passing off cases differ from those in cases involving the "extended form" of passing off (cases where the misrepresentations are about the general characteristics of a class of goods, rather than being about the origin or quality of a particular good). The consequence, Professor Davis argues, is that courts have been willing to afford especially generous protection to mark owners in extended-form of passing off cases, sometimes to the detriment of competition. Professor Davis proposes that for extended-form of passing off cases, courts import the average consumer test used in registered trademark infringement cases. Alternatively, courts should more freely admit that in extended form of passing off cases, they are engaged in an analysis that is more akin to a dilution or misappropriation inquiry than an assessment of likely consumer confusion.

\footnotetext{
51 Wal-Mart Stores., Inc. v. Samara Bros., Inc., 529 U.S. 205, 214 (2000). Justice Scalia was making the point in connection with rules for inherent distinctiveness of trade dress, but several scholars have invoked the argument in amicus briefs in other contexts. See, e.g., Brief of Amici Curiae Trademark Law Professors in Support of Defendant-Appellee, Marty Stouffer v. National Geographic Partners, LLC (CA No. 20-1208) (10th Cir.).

52 See infra, Chapter 12 . The U.K. courts have explicitly acknowledged that the construct should be empirical, which opens up space for significant reform proposals. See Graeme B. Dinwoodie \& Dev S. Gangjee, The Image of the Consumer in European Trade Mark Law, in Dorota Leczykiewicz and Stephen Weatherill (Eds), The Images of The Consumer in EU LAW 339 (2016).
} 
Michael Grynberg's chapter ${ }^{53}$ takes on the reasonably prudent consumer metric employed in the likelihood of confusion analysis in U.S. cases. That metric, observes Grynberg, incorporates no analog to the tort law duty of care. As a consequence, judges have freedom to define the reasonably prudent consumer in any given case as neither terribly reasonable nor especially prudent, resulting in various sorts of harms (e.g., depriving more attentive non-confused consumers of the benefit of the alleged infringer's activity). Grynberg would have courts instead equate the reasonably prudent consumer with a hypothetical "skillful consumer," defined as one who is familiar with the market and tools to navigate it. Doing so would place constraints on the scope of confusion liability, easing some of the pressure on countervailing doctrines such as the expressive use defense of Rogers $v$. Grimaldi..$^{54}$

Professor Grynberg has highlighted an important problem in confusion analysis. But one may wonder whether the problem is that the standard is more subjective than courts let on. Grynberg's argument calls to mind the earliest cases involving online commerce, in which reasonable consumers were portrayed as being utterly mystified by the perceived intricacies of search engines and hyperlinks, and it also calls to mind somewhat newer cases such as Toyota $v$. Tabari, in which Judge Kozinski portrayed the reasonably prudent consumers as remarkably agile online. ${ }^{55}$ Both portrayals may have reflected the reality of their respective times, of course. But the reasonably prudent consumer in Tabari seemed to possess skills suspiciously like Judge Konzinski's, and one might draw a similar impression from the older cases. Perhaps the problem with the reasonably prudent consumer metric is that judges are too prone to superimpose onto it their own sensibilities and limitations. Adopting a skillful consumer metric might not fix that.

Jeremy Sheff argues for abolishing the dilution claim. ${ }^{56}$ Adopting a contractualist framework for trademark law (in which trademark law exists to "facilitate the making and enforcing of promises between producers and consumers"), Professor Sheff shows that the dilution claim in such a framework has no meaningful role to play apart from the infringement claim. Most striking, perhaps, is Professor Sheff's sobering assessment of the likelihood for constructive reform. Sheff asserts that the dilution claim "has stubbornly resisted most efforts at reform-persisting in a stalemate that neither courts nor litigants seem willing to disturb," and confesses that "[h]opes for reform in such an environment are slim." While he admits that his approach entails a "radical reformulation of trademark law," and hence is likely to

53 See infra, Chapter 13.

$54 \quad 875$ F.2d 994 (2d Cir. 1989).

$55 \quad 610$ F. 3d $1171\left(9^{\text {th }}\right.$ Cir. 2010).

56 See infra, Chapter 14. Given the advancing constitutionalization of U.S. trademark law evidenced by Matal v. Tam, 137 S.Ct. 1744 (2017) and Iancu v. Brunetti, 139 S.Ct. 2294 (2019), some scholars expect that the courts may strike down the provision authorizing the dilution by tarnishment action, and perhaps the dilution by blurring action as well. See, e.g., Lisa P. Ramsey, Free Speech Challenges to Trademark Law After Matal v. Tam, 56 Hous. L. Rev. 401 (2018). 
meet with resistance, we take him to be hinting that trademark law reform more generally may suffer from conservatism such that upsetting the status quo may prove to be an arduous journey.

Stacey Dogan and Ansgar Ohly address the difficult problem of secondary liability in trademark law. Professor Dogan addresses the requirement that for secondary liability to attach, there must have been an instance of underlying direct liability. ${ }^{57}$ Professor Dogan argues that some courts have taken liberties with this requirement, converting what should be a direct infringement inquiry into a more expansive "roving unfair competition" assessment that does not insist that the direct infringer create confusion through its own product sales. Instead, underlying instances of direct liability spring from general search engine practices or from "dual-use" policies that may facilitate non-infringing uses along with infringing ones. Accordingly, she proposes that only instances of underlying direct infringement that cause harm on their own should be usable as the basis for secondary liability. That is, direct infringement for purposes of secondary trademark liability should require "(a) a use of the mark by the defendant, in connection with the sale or advertising of its own goods or services, (b) in a way that creates a likelihood of confusion between its goods and services and the trademark holder."

Part III concludes with a contribution from Ansgar Ohly, who offers a comparative perspective on intermediary liability ${ }^{58}$ Professor Ohly characterizes the problems with developing a nuanced law of intermediary liability as twofold: first, there are many interests to balance; and, second, there is a wide diversity of intermediaries, from those offering socially desirable or at least innocuous services (entities on the "green" end, such as domain name registrars) to those whose raison d'etre is to sell infringing goods (entities on the "red" end). The existing law of intermediary liability reflects a tension between certainty and flexibility, Professor Ohly observes. The presence of diverse types of intermediaries might counsel in favor of individually-tailored duties of care, as is evidenced in some opinions on copyright intermediary liability from German courts and the Court of Justice of the European Union. On the other hand, the immense data traffic across many online intermediaries suggests a compelling need for simple, standardized rules that can be applied at scale, perhaps automatically, without much human oversight. With view of these competing considerations, Professor Ohly lays out a set of questions that legislators should consider in crafting an effective legislative framework for intermediary liability that draws on lessons from both the U.S. and Europe. He also urges decisionmakers to consider combining legislative approaches with incentives for private ordering, the latter embracing collective agreements or court-mediated agreements between individual rights owners and intermediaries. One may wonder whether the motivation for

57 See infra, Chapter 15.

58 See infra, Chapter 16. 
reform in this area comes from the practicalities of intermediaries serving as de facto transboundary adjudicators, and/or from desire for transcendental safe harbor rules. ${ }^{59}$

What emerges from all of these contributions is a predictably complex mosaic of motivating forces that combine to drive trademark law reform. As always, we find an ongoing tug-of-war over the role of trademark protection in enhancing (or thwarting) domestic competition. But we also expect domestic judges to demonstrate increasing sensitivity to the international implications of their otherwise domestic trademark law decisions. We also anticipate considerably greater attention to regulatory reform. In addition, we see numerous other influences coming into play. In the US, for example, a judicial move towards the constitutionalization of trademark law is underway. Judicial impatience with the cost of resolving trademark disputes (and a tendency to curtail rights where litigating disputes is deemed "not worth the candle") is apparent in some cases. And the use of technology as a surrogate for enforcement will continue to rise.

59 Europe has such safe harbors, whereas the U.S. does not. See Kate Klonick, The New Governors: The People, Rules, and Processes Governing Online Speech, 131 Harv. L. Rev. 1598 (2018); Mark A. Lemley, Digital Rights Management: Rationalizing Internet Safe Harbors, 6 J. On Telecomm. \& High Tech. L. 101 (2007). For another example of a debate over the wisdom of transcendental rules interjected into trademark law, see Mark A. Lemley, Did eBay Irreparably Injure Trademark Law?, 92 Notre Dame L. Rev. 1795 (2017) (arguing that the eBay rule on injunctive relief in patent cases should not be imported into trademark law); Trademark Modernization Act of 2020 (Rules Committee Print 116-68, Dec. 21, 2020) $\S 226(a)$ (amending Lanham Act \$34(a) to provide trademark plaintiffs with a rebuttable presumption of irreparable harm for purposes of seeking permanent (or preliminary) injunctive relief for established (or likely) Lanham Act violations). 